\title{
Morality without Religion: Argument from the Autonomy of Reason
}

\author{
Crispin Ong'era Isaboke \\ Department of Humanities \\ Chuka University, Kenya \\ P.O. Box 109 - 60400, Chuka \\ Email: crisaboke@yahoo.com
}

\begin{abstract}
The question of whether a person can be moral without being religious is a critical one. It is a critical question because it is somehow difficult to draw the distinction between the two. It is a question of whether religion precedes ethics or ethics precedes religion. This has everything to do with whether reason is independent and autonomous or is subject to religion. There are people who believe that the two are inseparable, like a section of Muslims and followers of some other religions, who identify morality with religion, on one hand, while moralists would argue that the two are not the same. We are then left at a cross-road. This happens to be so because there are many ways in which religion has been seen to be, in one way or another, identical with ethics to the extent that you cannot teach or talk of ethics outside religion nor can you teach or talk of religion without making reference to ethics. The aim of this paper is to explore the two concepts; religion and ethics in close relation to mainstream world religions with the view of resolving the conflict between ethics and religion. This, in essence, shall have established the philosophical foundations of religion in a sense. In other words, the question revolves around reason, ethics, and religion; are they intertwined or are they not? If not, which order do they follow? The paper, therefore argues that religion is a product of reason while ethics is identical with reason.
\end{abstract}

Keywords: Reason, Ethics, Religion, Culture, Priority, Autonomy of Reason

\subsection{Introduction}

The term "reason," on one hand, is used in this context to mean the "mind," which is the rational faculty by virtue of which man is different from other animals; he is an intelligent being. By reason, therefore, man is a knower and a doer. Mind is divided into two other faculties; the intellect, by which man searches and attains intellective or universal knowledge, and the (free) will, by which man puts knowledge into action. Nyasani argues that the intellect "[...] is the capacity $[\ldots]$ of the mind whose task it is to understand, think and reason[...] It also happens to be the faculty from which the will flows." ${ }^{, 2}$ This implies that action, which is a function of the free will, proceeds from knowledge, which is a function of the intellect. The two faculties, in other words, work, and have to work, in harmony for the perfection of man. Moreover, this is the reason why to act according to reason is to act rightly; and one achieves that by conforming his free actions to knowledge; that is to say that there is an "ought" (to be done), a moral obligation to which any rational being must conform their actions. This is a dictate of the human nature and how it functions. Religion, on the one hand, is a term used to refer to everything that has to do with belief and involves worship of a god or deities, ritual and a moral code. It is "[...] an institutionalized system of beliefs and values shared by a group and grounded in faith and the worship of a Supreme transcendent being (s)." "Thus, religious beliefs are normally communal and an expression of worship. Religion is moreover ritualistic in that those beliefs are enacted and made operational through ceremonies. An ethical code is also central and pivotal to religious life whereby rules about human behavior are established and they define how followers ought to conduct themselves to constitute themselves as good persons. Furthermore, ethics is a term derived from the Greek words ethos or ethikos which translates to character. Its Latin equivalent is "mores," which in this case would mean customs or habitsofaperson. Ethicsor Moral Philosophy, therefore, deals with human behavior, that is, how we ought to conduct ourselves as human (rational) beings.

\footnotetext{
${ }^{1}$ The word "reason" in this context also means "the moral law" which dictates that good ought to be done and evil avoided.

${ }^{2}$ Joseph M. Nyasani, MetaphysicalPsychology: RationalPsychology (Nairobi: Consolata Institute of Philosophy Press, 2013) p. 27.

${ }^{3}$ Judith A. Boss, Ethics for Life: A Text with Readings, Third Edition, (New York: McGraw Hill, 2004) p. 145.
} 
It examines human acts or conduct from the aspect of their rightness or wrongness. In other words, conduct has the quality of being good or bad, right or wrong.

With the above understanding, it is now incumbent on the writer to argue our case on the relation between religion and ethics. This cannot be achieved without looking at the two in relation to culture, given that both are aspects of culture.

\subsection{Religion in Relation to Culture}

Culture can be defined as "the sum total of what a given group of people think (beliefs, values), what they do (behavior) and what they produce (rituals and symbols)." "It means all that a people practice and how they practice them. Culture in this sense embraces the entire world-view of a people; that is, a people's way of life, a weltachaung . A culture defines and gives people their true identities. It is inconceivable to think of a human being without a culture. "[...] culture signifies that totality of customs, techniques, and values that distinguish a social group, a tribe, a people, a nation $[\ldots]^{p, 6}$

In addition, cultures are characterized with languages that bear the meaning and expression of those specific cultures. In point of fact, there cannot be culture without language. It is within the confines of language that traditions, histories, and values of a specific culture, commonly known as heritage, are preserved and passed from one generation to another. Yet in Africa alone there are "a great diversity of peoples, cultures, religious systems and languages in close confines." What this means is that different cultures practice different religious beliefs relative to their culture. The Abagusii, ${ }^{8}$ therefore, would worship a god who resides in the $\mathrm{Sun}^{9}$ and who is the provider of everything by dedicating a new day to him at sunrise while facing it; apparently asking for blessings for the day. The Agikuyu would face Mt. Kenya and express their gesture of worship to a god who also provides for all their needs but resides at the mountain. This is why all the water that nourishes their lives and crops comes, or is believed to come, from the mountain. It must be accepted therefore, that religion must be influenced and conditioned by the intrinsic organization of each specific culture and that the differences of religions are due to that fact. Religion in this sense reduces ethics to what it considers right and wrong; making it subservient to it.

Given that no culture is exactly identical with the other, religious beliefs would essentially be different depending on the perception of each culture as well as what they hold dear, meaning that even their ethics would be limited by that perception: "All cultures have distinctions between what they consider good and what they consider bad; what they consider right and what they judge to be wrong." ${ }^{, 10}$ But it must be borne in mind also that some of the acts that some cultures hold as values are not held as values in other cultures, while those acts held as vices are not necessarily vices in other cultures. Thus, one culture cannot hold as vice what others hold as virtue and the converse is also true. Understood in this manner, right and wrong is destroyed since we cannot talk of the "ought to be done" by all human beings; that is to say that the moral obligation does not exist according to which all human beings have to act by conforming their actual acts to it in order for them to act virtuously while failure to conform their actions to it would make their actions evil and therefore hold them responsible of them.

Looking at virtuous acts from a religious perspective would only imply that acting virtuously or doing the good is acting according to the dictates of one's religion (not reason). Conversely, acting against the teachings of religion would mean doing evil. Good and evil would in this sense be reduced to what is religious. Yet with numerous religions and even denominations among the same religion which do not however hold same teachings, it would be impossible to think of acts that are good in themselves and which therefore ought to be done; acts that are universally accepted by any human being. In truth, it would as well be defeatist in such circumstances to argue that there is good and evil; what would be the meaning of a certain good for a Catholic to a Seventh Day Adventist ${ }^{11}$ who holds a different view on the same? For instance, it is an undeniable fact that for the Seventh Day Adventist, Saturday is the Sabbath Day in keeping with the Jewish traditions that must be held holy by all their faithful.

\footnotetext{
${ }^{4}$ John Lukwata, Integrated African Liturgy, Revised Edition (Eldoret: AMECEA Gaba Publications, 2011) p.20.

${ }^{5}$ Weltachaungis a Germany word that means the totality of a people's way of life, which can be equated to what we call in English world-view.

${ }^{6}$ Battista Mondin, PhilosophicalAnthropology (Rome: Urbaniana University Press, 1991) p. 146.

${ }^{7}$ Lukwata, p. 21.

${ }^{8}$ Kisii refers to a Bantu speaking group that resides in the Western part of Kenya bordering Luos, Kurias, Kipsigis AndMaasais while Gikuyu is another Bantu speaking group around the Mt. Kenya region.

${ }^{9}$ Sun is the English translation of the Ekegusii term Erioba in which the god of the Abagusii, known as Engoro, resides.

${ }^{10}$ Brian Cronin, Value Ethics: A Lonergan Perspective (Nairobi: Consolata Institute of Philosophy Press, 2006) p. 133.

${ }^{11}$ SeventhDayAdventists is a Christian Denomination which worships on Saturday.

112
} 
Yet for the Catholics, Sunday is the day of the Resurrection of the Lord without which Christianity would be nonexistent; the critical question is "which is the appropriate day of worship?" What sense does this make to a Muslim who does notrecognize any of the two days but rather carries his holy activities on Fridays? What about a non-believer? Or must every person subscribe to a religion?

\subsection{The Inseparability of Religion and Ethics: A Mere Perception}

In his book, Value Ethics: A Lonergan Perspective, Brian Cronin argues that "many who espouse religious values do not see the need for a defense of distinct moral values." 12 In other words, they identify their religion with an ethical code identical to, and inseparable from, it. Yet every religion has an ethical code different from those of other religions. So, however identical a religion is going to be with its ethical code, this view reduces ethics to relativism given that that ethical code will only apply and be sensible to that religion alone. Any other practices that do not respect that ethical code are, by virtue of that, evil and sinful. This essentially means that religion cannot be separated from ethical values; a perspective that would be interpreting right and wrong in accordance to a people's religious beliefs but not in accordance to reason. What this means is that followers of any one religion would definitely consider as superior their ethical code and in turn look down on, and treat with contempt, those who hold different views. Yet reason is what makes a person human, not religion. If religion were to make one human, then it would logically follow that all human beings would not only belong to one homogeneous religion but would also be necessarily religious, which unfortunately is not the case.

Cronin adds that Religious groups normally teach moral values as part of their religious way of life and they provide powerful motives to live well, to condemn immoral behavior, to promote virtue and curb vices. ${ }^{13}$ It is a fact that every religion teaches her followers on how to live well, and they connect living well with reward of a certain kind in a later life.It also relates not living well to some form of punishment in an equally later life. This explains why Christians, for instance, talk of heaven and hell; those Christians who live according to their ethical-religious ideals shall inherit the kingdom of heaven while those who do not (sinners) shall perish eternally in hell. Moreover, "generally, I considerate (sic) true that religious values trump moral values. A religious perspective is more comprehensive, more ultimate, and more profound, than a moral perspective." ${ }^{14}$ In addition, "for a religious man, nature is never only 'natural'; it is always fraught with a religious value [...] for the cosmos is a divine creation; coming from the hands of the gods, the world is impregnated with sacredness. " ${ }^{15}$ Therefore, Cronin sees religion as something necessary for man.

On the contrary, I must argue without fear of doubt that motivating people to act as they ought would be as unethical as it would be threatening them. Instead, acting rationally is a duty of our human nature and we do not need to be persuaded, motivated or even threatened to do so. I, therefore, differ, and reasonably so, with my one time professor of philosophy, Rev. Fr. Brian Cronin, when he argues that a religious perspective is more comprehensive than a moral one. Alternatively, even where the universe could be a divine creation, as Cronin says, what is critical is the purpose of creation. It is my strong conviction that if God created man, he must have created him for a purpose. Having created him rational, God must have intended that man be rational, and therefore, moral; not to be religious. That being the case, why would anybody want to look at everything from a religious point of view rather than from the rational point of view? Is reason not universal and autonomous while religion can be subjected to it?

We know for fact that when people worship, they praise that which in their thinking has the highest worth or value: "God is worshipped because God represents perfect goodness." ${ }^{16}$ In point of fact, religion is faith based whereby a man of faith in God believes that there is a God and that that God is all-powerful in whom everything is possible. Again, this is the reason why people believe in prayers. But, the question of whether religion precedes ethics or vice versa is a question of whether religion is natural or artificial. Is the moral natural or conventional? If both the moral and the religious are natural; does that imply that both are inseparable with reason? These are the critical questions in this discussion. We are first human beings before we are religious. Think of any religious organization, one is not born a religious but one acquires the religious values and traditions through socialization. We are victims of the religions that are dominant in the places we are born and bred. Hardly can one be a Christian, for instance, if they are born in Zanzibar; while it is equally almost impossible for one to be a Muslim if they are born in Rome. That is to say that most people belong to their religions not by choice but by circumstances.

\footnotetext{
${ }^{12}$ Cronin, p. 8 .

${ }^{13}$ ibid.

${ }^{14}$ ibid.

${ }^{15}$ MirceaEliade, The Sacred and the Profane: The Nature of Religion (New York: Harcourt, Brace \& World, Inc., 1959) p. 117.

${ }^{16}$ Boss p. 145.
} 
Had religion come prior to ethics, as we have observed above, there would be only one universal religion for all human beings, given that every human being would have been born religious. Morality would then be a product of religion whereby only one religion would exist with one universal morality identical with it. But it defeats the principles of logic to argue so since it would mean that religion existed long before we were born; but how is that possible and where could it have been? The multi-religious groupings, therefore, evident in our society today, are the clearest indication that religion is rather acquired than natural. That which is natural is always present and inseparable with humanity, and that is not the case with religion. The problem gets even compounded when different faiths embark on a mission to win converts to their faiths, making it more evident that religion is something of a later development. Religion could not have been simultaneous with rationality, and therefore ethics.

Religion puts boundaries to ethics; it sets limits for reason so that the latter has to exercise its activity within those limits of religion. It limits and commands that followers of that particular religion act in accordance with the dictates or teachings of that religion, which can loosely be called her morals; and any act to the contrary is perceived as evil. It therefore limits reason yet the only limit to reason in conduct should, as we have already said, and must, be the good. What this essentially means is that man should act freely within the limits of that which is good. In any case, religions are different and if each religion looks at morality from her point of view that would reduce morality to relativism and in the end deny and destroy it. That would be equally subjecting reason to religion yet reason is independent and autonomous. The further inference would be that there exists as many gods as there are religions, which is not only ridiculous but also illogical. The reason for this is that if what is good is relative to religion that would be tantamount to saying that there is no good and evil; the two would depend on which religion one belongs and subscribes to.

In point of fact, the difficulties of separating religion from ethics are live on the grounds that many people look to their clergy both as religious authorities as well as moral ones: "people come to the clergy with ethical problems such as marital problems and personal conflicts." ${ }^{17}$ Every religion, therefore, has an intrinsic connectedness with its ethics. And this makes it difficult for its followers to look beyond their religions to discover the true worth of the human person to be found in reason alone. In addition, "the concept of God in the major world religions - Judaism, Christianity, Hinduism, and Islam - is so intimately connected to the concept of moral goodness that the moral code is incorporated right into the doctrine of these religions." 18 This further explains why for Christians, for instance, the study of sacred scriptures is important, in part, because it teaches how to distinguish right from wrong. Yet in many Muslim countries such as Saudi Arabia and Morocco, the law of the sacred texts - the Qur'an - is the law of the land and applies to everyone living in that country. ${ }^{19}$ In spite of that fact, that alone does not and cannot mean that scripture is the only source of moral guidance or that morality is relative. Muslims belief that the Qur'an does the same and every other religion but all that can be implied from the fact that religion cannot be identical with ethics. It only demonstrates that religious ethical teachingsare subservient to ethics itself, thus the latter precedes the former.

It must be noted, nevertheless, that in the Jewish religion, Roman Catholicism, and mainstream Protestant religions, the independence of religion from ethics is characterized by the fact that basic moral principles are also held to be universal and discoverable through other means such as the use of reason or intuition. ${ }^{20}$ But when it comes to Muslims, though not all, ethics is viewed as inseparable from religion but is built entirely on it. For them, an action is right only if, and for the reason that, God commands it: "Religion informs not only the Muslim's personal life but also the basis of public policy." 21 According to them, human beings are not expected to discern right from wrong but to unquestionably submit to the will of God.

In addition, whereas a number of religions are monotheistic, quite a number are equally polytheistic nor do all (religions) regard God as a divine entity with whom human beings can have a personal relationship. A section of the Hindu, for instance, believes that there is no God but truth. This is the reason why Mahatma Gandhi maintained that we must learn to love and respect even the lowest of living beings. Budhism and Jainism, which developed out of Hinduism, also had a major influence on Gandhi's moral philosophy. Neither Budhism nor Jainism is strictly speaking a religion because belief in God or a transcendent being is not part of either worldview. ${ }^{22}$

In light of the above, we can safely say that the relationship between religion and morality may be looked at from two different angles; the divine command perspective and the natural law perspective. According to the former, morality is

\footnotetext{
${ }^{17}$ Boss, p. 145 .

${ }^{18}$ ibid. p. 146.

${ }^{19}$ ibid.

${ }^{20}$ ibid.

${ }^{21}$ ibid.

${ }^{22}$ ibid. 
relative to God's commands and, therefore, subject to change from time to time or person to person; while in accordance to the latter, morality is based on universal, unchanging principles and that God commands or approves something because it is right prior to the command.

Moreover, for the former, there are no universal moral standards by which to judge God's commands. No other justification is necessary for an action to be right other than that God commanded it. God's reasons are ultimately unknowable to humans, and for that same reason, God's commands must be accepted on faith: to question God's commands or to demand independent nonreligious reasons for accepting a divine command shows lack of faith. When Abraham was asked to offer his son Isaac as a sacrifice, he didn't object but obliged without question and that is how a man of faith should behave or conduct himself. But for the latter, God commands an action because it is moral beforehand and independently of God's commanding it at that moment. In essence, therefore, morality is grounded in the rational nature of man rather than being relative to divine command, human feelings, and cultural norms. "By 'nature' they mean human nature unlike physical nature, human nature is seen as nonmaterial and rational [....] Human nature is free and autonomous." ${ }^{, 3}$ By being free therefore, man is capable of acting in accordance with his rational nature or against it, although he also knows naturally of the moral law that he is under obligation to obey. In essence, the moral obligation according to which 'good ought to be done' and 'evil ought to be avoided' is a true expression and a reflection of the rational nature of man, given that conscience connects the will, which is essentially free, with this moral order. What that substantially means is that through conscience, which is a practical judgment of reason, we are commanded at that moment we want to act, to do good and refrain from evil. Thus, conscience acts as a guide to our future actions and always commands that we do the good; it does not lie:"Conscience has its own power and autonomy. It functions: judging us [...] but conscience speaks with a voice that is not easily silenced. Deep down inside the person, it still makes itself audible [....] It is conscience that does the shaking, and it is we whom it tries to punch into shape. $^{24}$

That explains why Thomas Aquinas argues to the effect that moral law was created by God as part of God's divine plan for the universe, while Aristotle holds the view that natural law has always existed as part of the natural order. That notwithstanding, all natural law theorists agree that it lies outside cultural norms and laws and that the moral laws embedded in our nature as humans take the form of a universal code that we all ought to follow. What about ethics and culture?

\subsection{Ethics: An Essential Component of Culture}

Evidently, just like religion, ethics is also a component of culture alongside language, traditions and history as well as taboos, commonly known as the dos and don 'ts. While religion focuses on ways of worship and relating with a deity or god, ethics deals with conduct, or particularly human acts. ${ }^{25}$ It takes cognizance of the fact that human acts have the quality of being good or evil by either conforming to reason or not. That is to say that on their own, human acts can be right or wrong, good or bad.

Therefore, it is true, and absolutely so, that to act virtuously (ethically) has no direct relation with religion. Outside religion there is the moral obligation that dictates to us that good ought to be done. As a rational being, therefore, man has the duty to act in accordance to reason, not in order to achieve anything in return, but simply because it is good and rational to do so; it is the right thing to do. For this reason, the good can be defined as that which is in accord with reason. That is to say, good or virtue is that act which conforms to the moral law according to which knowing the good implies free response of the will to it (the good). This further means that to be free is to do the good without failure or exception.

Consequently, to act responsibly is to act according to reason; to do the "ought" to be done since this is a rational duty. Man cannot be said to be free where freedom means ability to do whatever one wants, whether good or evil. Man is not free to do evil since this will be going against his nature. The reason for this is that man acts for a purpose and happiness is the highest good that man attains only by virtuous acts. Thus, man must always act in such a way as to direct himself to his last end, which is happiness, by only doing the good. Acting contrary, therefore, signifies acting against reason by either doing the "ought not" or not doing the "ought." This would deny man his last end which is undesirable due to the fact that man naturally desires happiness. It is natural of him to seek happiness and find satisfaction in it. Yet this cannot be achieved except by acting in strict adherence to the moral law. It would be against

\footnotetext{
${ }^{23}$ ibid.

${ }^{24}$ Cormac Burke, Man and Values: A Personalist Anthropology (Limuru: Kolbe Press, 2007) p. 72.

${ }^{25}$ Humanacts are those acts that are in man's control so that he can choose to do or not do them. They are voluntary and deliberate and thus man is responsible for them. They are free acts as opposed to conditioned ones, technicallyknown as acts of man which man shares with animals.
} 
man's nature to do evil. In view of this, evil is acting without reason while good is acting, at least, not without reason. From this, we can aver that there is no freedom in doing evil since there is no alternative route or shortcut to happiness. Pope Francis ${ }^{26}$ maintains that "even those who do not believe in God can ascend to heaven if they lead good and honorable lives. ${ }^{, 27} \mathrm{He}$ goes on to emphasize that "the Lord has redeemed all of us, all of us, with the blood of Christ, all of us, not just Catholics. Everyone!" ${ }^{28}$ My interest on what the Pope is saying is not whether atheists will go to heaven if they acted rightly, rather that even them ${ }^{29}$ can make good moral decisions. It, therefore, means that one need not be religious to know the good and do it. With or without religion, by his rational nature, man is capable of knowing and distinguishing good and evil. Consequently, man can make a free decision to act morally (the only reason why the Pope says they can also go to heaven). The point of the Pope is that regardless of whether or not one is religious, it is imperative that they be moral by practicing virtue or acting according to the dictates of reason. It is my conviction that religion is relevant inasmuch as it guides man in morals, not morals guiding man to be religious. Put in another way, one could not be religious if one were not rational. Yet morality constitutes a necessary part of being rational. Morality cannot be separated from rationality, religion can. This is the reason why we have human beings (rational and therefore potentially moral) but who are at the same time atheists. We cannot have people who are religious without being potentially moral. The fact that religion is separable from reason while ethics is not answers our leading question in this paper: can there be morality without religion? This question therefore can be answered in the affirmative - it is possible to be moral without being religious. The Pope correctly adds that "the question for people who do not believe in God is to listen to their consciences. Also for those without faith, sin is going against your conscience., 30

On this, the Pope recognizes the central role that conscience plays in moral decisions and actions; that of guiding man in his actions by commanding that he does the good and refrains from doing evil in particular instances. He adds that "listening to it and obeying it means making up one's mind about what is good and evil." "31 This signifies that what is sinful in religious circles can somehow be equated with moralevil. This means that acting against the teachings of one's religion leads to sin while acting against reason or conscience leads to moral evil. This should not however be construed to mean that the two are identical in nature. It is possible to act morally without acting religiously and it is also possible to act religiously without acting morally. Furthermore, acting in the dictates of conscience conforms our acts to the moral law (reason) and they by that fact become good but disobeying conscience goes against the moral law and by that fact results in evil. All known cultures have this kind of moral consciousness and this implies that this is naturally known by man. It is irrefutable that action proceeds from the intellect after the process of deliberation and decision making. In other words, to act is to put knowledge into use. Nyasani states: [...] the intellect is the capacity (faculty) of the mind whose task it is to understand, think and reason...it may translate into mind or intelligence having the potential or capacity to conduct mental and rational activities lurking all the while in the state of potency in the human consciousness. It also happens to be the faculty from which the will flows. ${ }^{32}$

From Nyasani's observation, it can be inferred that action flows from knowledge. We act on the knowledge that we have, and particularly in ethics, knowledge of good and evil. Man therefore has the potentiality as a rational being to know good and evil; he is also capable of doing good and avoiding evil yet he is equally under obligation to do good and avoid evil at all times. Wherefore, when he conforms his free acts to knowledge he acts rightly and when he does not conform his free acts to knowledge he acts wrongly. Furthermore, Nyasani sees the will as: "[...] the faculty of conscious and deliberate choice of action. It is the faculty of human volition which, in its functionality, must necessarily entail actions which are freely willed and which, in moral education, are referred to as voluntary actions. All human acts as opposed to acts of man are voluntary, deliberated and consciously undertaken. They take place as a result of some conscious and voluntarily willed decision and hence create unshakeable moral, legal and social responsibility for an individual". ${ }^{33}$

\footnotetext{
${ }^{26}$ Pope Francis is the World leader of the Roman Catholic Church and Bishop of Rome.

${ }^{27}$ www.straitstimes.com/world/pope-says-atheists-can-take-moral-decisions-like-catholics/retrieved on April 25, 2018 .

${ }^{28}$ www.straitstimes.com/world/pope-says-atheists-can-take-moral-decisions-like-catholics/retrieved on April 25, 2018.

${ }^{29}$ Them refers to "those who do not believe in the existence of God," atheists.

${ }^{30}$ www.straitstimes.com/world/pope-says-atheists-can-take-moral-decisions-like-catholics/retrieved on April 25, 2018.

${ }^{31}$ www.straitstimes.com/world/pope-says-atheists-can-take-moral-decisions-like-catholics

${ }^{32}$ Joseph M. Nyasani,Metaphysical Psychology: Rational Psychology (Nairobi: Consolata Institute of Philosophy

Press, 2014.

${ }^{33}$ ibid. p. 31 .

116
} 
Moreover,"a conscious decision and deliberation, must, ipso facto, flow and emanate from the intellect. The intellect, therefore, is always behind the acts of the will explicitly or implicitly, or, in other words, the will must always involve the intellect in producing its own effects, unless it chooses to exceed or disobey the dictates and specifications of the intellect. ${ }^{34}$ From the above we can infer that human acts are free acts and are done without coercion or pressure of any kind, but also that one cannot act without knowledge. It is in the search for knowledge of the rightness or wrongness of human acts that deliberation is a sine qua non condition.

Hence, even where the two are components of culture, ethics embraces all ways of a people's behavior or conduct (from the Greek ethos) while religion does not. In essence, there is always a good way to act religiously but there cannot be a religious way to act ethically. Religion, in other words, is practiced within the morals of a culture. Be that what it may, culture is not universal, hence religion too; since people of different cultures practice and cherish different religious beliefs. By that fact, religion is culture-specific; it is one of the components of any culture. It is part of what a people hold dear and cherish as their values. In other words, religion is a cultural value. Religion is particular; for instance, Christianity is a borrowed religion from a borrowed Western culture, which replaces a people's cultural beliefs and practices as a superior religion. Nevertheless, it is not universal but ethics transcends and permeates all cultures and is ipsofacto universal since it applies to all human beings. On the same wavelength, Islam is a borrowed religion from the Arab culture neither is it universal; it only applies to a specific group of people, precisely those who have accepted the Arab culture. But all cultures are rational and therefore are founded on morality; man is social by nature.

What transpires from the above is that ethics is not culture-specific as religion is; rather, every culture recognizes the fact that there is a difference between good and evil but also that good ought to be done and evil ought to be avoided, what the good or evil is notwithstanding. Thus, ethics, by virtue of that, goes beyond culture, is universal and cannot be reduced to religion. Instead, Religious beliefs can at best hinder free will and freedom, both of which should only be limited by the good because of the rational (moral) obligation to do that which is good; in other words, for man to be free, he must do anything insofar as it is good. However, by virtue of the fact that man is a rational being, blessed with the faculties of the intellect and the will; he is naturally an ethical being. This is so for the reason that the freedom of the will makes it possible for man to be held responsible for his actions, and ipso facto, a moral being. Morality cannot be separated from reason and the two together define man as a rational being. For what could a human being be without reason? Could he have been any better than a mere animal? Still, could there have been religion? Religionis a product of reason. Animals do not have reason and therefore do not practice religion. Effectively, any argument that religion is prior to ethics is defeatist for then even animals could be religious though not rational. Yet man alone practices religion.

\subsection{Conclusion}

In conclusion, therefore, ethics is enshrined in the very rational nature of man and is inseparable with it while religion is a product of reason and separable from it. For this reason, we can strongly affirm that ethics without religion is possible but religion without ethics is impossible. Accordingly, religion and ethics are neither identical nor does religion precede ethics; rather, morality constitutes a part of the rational nature of man and is identical with it while religion is a product of the two. The moral instincts are natural, and therefore, simultaneous with reason while religion is not.

\section{References}

Boss, Judith A. Ethics for Life: A Text with Readings. Third Edition. New York: McGraw-Hill, 2004.

Burke, Cormac. Man and values: A Personalist Anthropology. Limuru: Kolbe Press, 2007.

Cronin, Brian. Value Ethics: A Lonergan Perspective. Nairobi: Consolata Institute of Philosophy Press, 2006.

Eliade, Mircea. The Sacred and the Profane: The Nature of Religion. New York: Harcourt, Brace \& World, Inc., 1959.

Lukwata, John. Integrated African Liturgy.Revised Edition.Eldoret: AMECEAGabaPublications, 2011.

Mondin, Battista. Philosophical Anthropology. Rome: Urbaniana University Press, 1991.

Nyasani, Joseph M. Metaphysical Psychology: Rational Psychology. Nairobi: Consolata Institute of Philosophy Press, 2014.www.straitstimes.com/world/pope-says-atheists-can-take-moral-decisions-like-catholics/retrieved on Aril 25, 2018.

\footnotetext{
${ }^{34}$ ibid.
} 